\title{
A Herpetofaunal Survey of Northwestern Mongolia with the First Country Record of the Moorfrog, Rana arvalis Nilsson 1842
}

Munkhbaatar Munkhbayar ${ }^{1}$, Terbish Khayankhyarvaa ${ }^{2}$, Onolragchaa Ganbold ${ }^{1}$, Zoljargal Purevdorj $^{3}$, Burnee Mundur ${ }^{4}$, Gurragchaa Jargalsaikhan $^{1}$, and Munkhbayar Khorloo ${ }^{1}$

${ }^{1}$ Department of Biology, Mongolian National University of Education, Ulaanbaatar, Mongolia (mmunkhbaatar@msue.edu.mn)

${ }^{2}$ Department of Biology, School of Science, Mongolian National University, Ulaanbaatar, Mongolia

${ }^{3}$ Department of Forest and Environmental Resources, Chungnam National University, Daejeon, Republic of Korea

${ }^{4}$ Department of Biology, Mongolian National University of Medical Sciences, Ulaanbaatar, Mongolia

All photographs by the senior author.

$\mathrm{A}^{\mathrm{n}}$ mphibians and reptiles in Mongolia receive a relatively low conservation priority compared to mammalian and avian species. This might be a reflection of the relatively few recorded species and/or a lack of interested researchers. Historically, the renowned traveler and naturalist P.S. Pallas, whose expeditions took place in northern Mongolia in the 18th Century, collected data on the life history of amphibians and reptiles in Mongolia (Kuzmin et al. 2017). Primarily Russian (former Soviet Union) scientists gathered additional scientific information on these animals in Mongolia in the 19th and 20th Centuries, including the expeditions of Potanin in 1883 (Potanin 1889), Kozlov in 1923-1926 (Kozlov 1949), and R.C. Andrews, whose expedition reached central Mongolia (Pope 1931). Based on data from these expeditions, Bannikov (1958) published the first overview of the Mongolian herpetofauna. Since the second half of the 20th Century, Mongolian scientists' role rapidly increased; they conducted several local expeditions focusing on the herpetofauna, often in collaboration with Russian scientists (e.g., Shagdarsuren 1958; Munkhbayar 1971, 2009; Danzan 1963; Munkhbaatar 2003). The majority of these previous studies were limited to the eastern, central, and southern parts of Mongolia. These expeditions yielded records for a total of six species of amphibians and 22 species of reptiles.

A harsh continental climate dominates Mongolia, especially in the southern regions, which are dominated by deserts and semi-deserts (Kuzmin et al. 2017). Absolute temperatures fall to as low as $-50{ }^{\circ} \mathrm{C}$ during winter and reach as high as 58 ${ }^{\circ} \mathrm{C}$ in summer and relatively low precipitation characterizes many areas (Jambaajamts 1989; Kuzmin et al. 2017). These conditions are responsible for the very low species richness of amphibians in the country. Most amphibians that have been recorded for the country are limited to northern Mongolia, a region with relatively higher precipitation than the rest of the country. In contrast, despite the country's harsh climate, Mongolia hosts a relatively diverse suite of reptiles, especially in the southern parts of the country.

Some researchers (e.g., Borkin and Kuzmin 1988; Munkhbayar et al. 2001) included the Moorfrog (Rana arvalis) in the Mongolian herpetofauna without any evidence of its presence in the country. Based primarily on information from local people, these researchers hypothesized the existence of $R$. arvalis in western and northern Mongolia, a region not covered by previous herpetological expeditions. This species is widely distributed in the moorlands of Eurasia, but is most commonly found in European countries, with just a few records in Asian Russia (the region that borders Mongolia), Kazakhstan, and Central China (Kuzmin 1999; Kuzmin et al. 2009).

Our main objectives for this study were to assess the species diversity of amphibians and reptiles in northwestern Mongolia and confirm the presence of Rana arvalis in the country.

\section{Materials and Methods}

Study sites. - We conducted our field surveys from June to July 2019 in northwestern Mongolia. Our study sites included Burenkhaan, Khyrgas Lake, Naranbulag, Tavan Burgas, Shar Uzuur, and Ulaan Taiga (Table 1; Fig. 1). Of these, Tavan Burgas, Shar Uzuur, and Ulaan Taiga had been suggested as candidate regions for the possible existence of Rana arvalis (Borkin and Kuzmin 1988; Munkhbayar et al. 2001; Terbish et al. 2006). Our western study sites (northwestern Mongolia) in Uvs Province are in the Great Lakes Basin (GLB; a partial 
Table 1. Description of study sites in northwestern Mongolia. Dominant plant species of study sites were identified using Olziikhutag (1989).

\begin{tabular}{ll} 
Study Sites & Description of site \\
\hline Burenkhaan $\left(49^{\circ} 56^{\prime} 43.3^{\prime \prime} \mathrm{N}, 99^{\circ} 22^{\prime} 13.7^{\prime \prime} \mathrm{E}\right)$ & The Delgermurun River Basin is in the mountain forest region. \\
\hline Khyrgas Lake $\left(49^{\circ} 40^{\prime} 13.3^{\prime \prime} \mathrm{N}, 92^{\circ} 76^{\prime} 47.8^{\prime \prime} \mathrm{E}\right)$ & $\begin{array}{l}\text { Near sandy lake shore. Dominant plants include Salsola passerine, Astragalus ammodytes, } \\
\text { and artemisia tomentella. }\end{array}$ \\
\hline Naranbulag $\left(49^{\circ} 28^{\prime} 42.8^{\prime \prime} \mathrm{N}, 92^{\circ} 56^{\prime} 73.5^{\prime \prime} \mathrm{E}\right)$ & $\begin{array}{l}\text { Semi-desert region near Khyrgas Lake. Dominant plants include Salsola passerine, } \\
\text { Astragalus ammodytes, and artemisia tomentella. }\end{array}$ \\
\hline Tavan Burgas $\left(50^{\circ} 52^{\prime} 79.5^{\prime \prime} \mathrm{N}, 94^{\circ} 00^{\prime} 81.3^{\prime \prime E}\right)$ & $\begin{array}{l}\text { Uvs River Basin. Dominant plants include Salix ledebouriana, Populus pilosa, Betula } \\
\text { rezniczenkoana, and Carex spp. }\end{array}$ \\
\hline Shar Uzuur $\left(50^{\circ} 35^{\prime} 66.1^{\prime \prime} \mathrm{N}, 94^{\circ} 31^{\prime} 76.1^{\prime \prime E}\right)$ & $\begin{array}{l}\text { Open semi-desert region in the Great Lakes Basin. Dominant plants include Salsola } \\
\text { paulsenii, Cargana leucophloea, Eragrostis cilianensis, and Allium stellerianum. }\end{array}$ \\
\hline Ulaan Taiga $\left(50^{\circ} 86^{\prime} 79.2^{\prime \prime} \mathrm{N}, 98^{\circ} 03^{\prime} 20.1^{\prime \prime} \mathrm{E}\right)$ & $\begin{array}{l}\text { Mountain taiga with numerous small ponds. Dominant plants include Carex schmidtii, } \\
\text { Lemno minor, and Hippuris vulgaris. }\end{array}$ \\
\hline
\end{tabular}

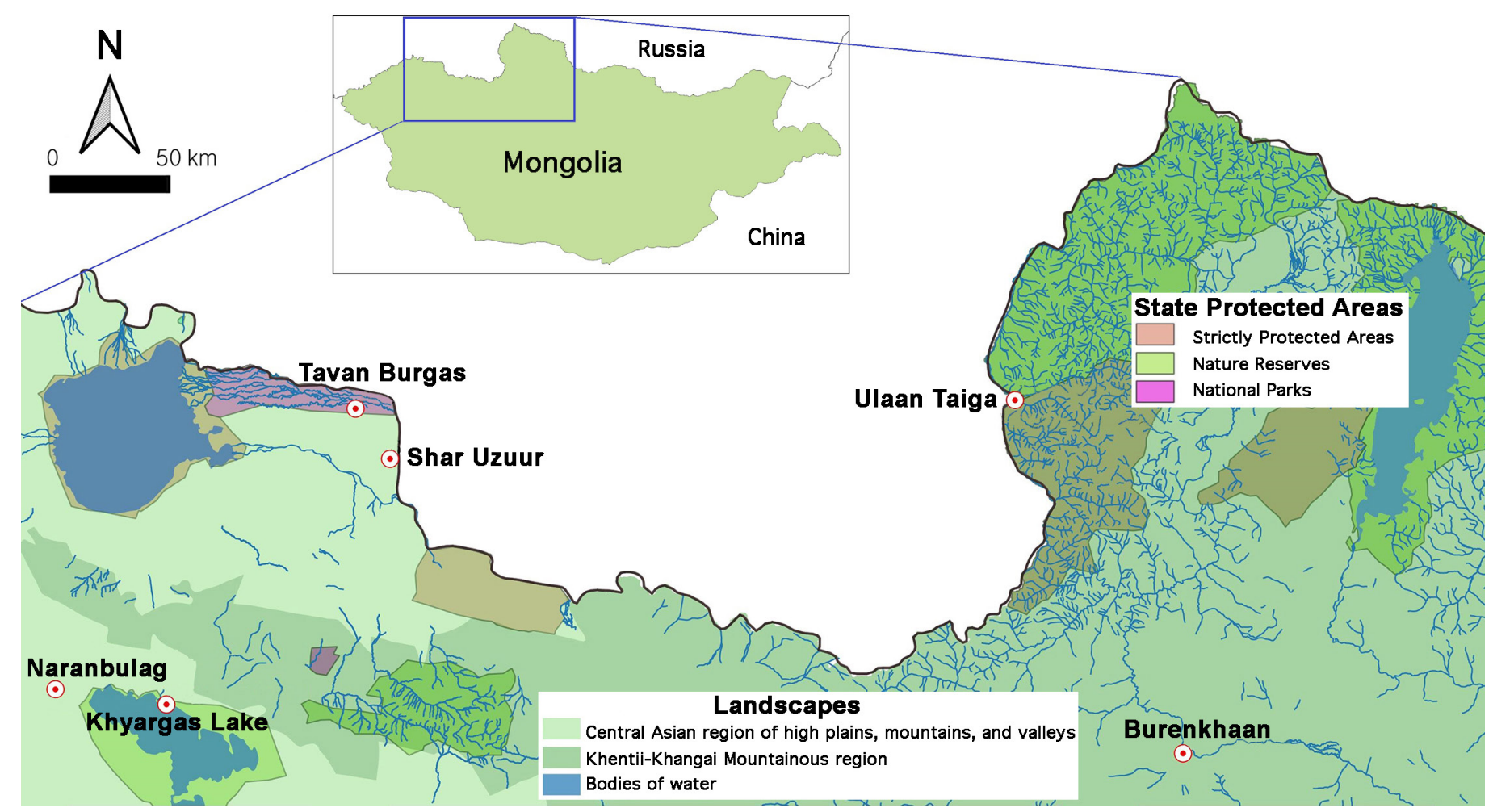

Fig.1. Map of northwestern Mongolia indicating locations of study sites.

semi-desert region), our northern study sites are in Khuvsgul Province, which belongs to the Region of Khuvsgul Taiga (RKT), and our remaining sites are in Zavkhan Province, located in the Region of Forest Steppe (RFS). The climate of northwestern Mongolia is colder than other regions, with average air temperatures in January of $-25--30{ }^{\circ} \mathrm{C}$ and in July of $15-20^{\circ} \mathrm{C}$ (Jambaajamts 1989). The elevations at our study sites were $800-3,000 \mathrm{~m}$ asl, with landscapes mainly characterized by north-facing slopes with steppe forest, mountain forest, or taiga forest and annual precipitation of 119-220 mm (Jambaajamts 1989). The GLB and RKT are recognized as relatively biodiverse regions, with hundreds of species of migratory and non-migratory birds, including the globally threatened Dalmatian Pelican (Pelecanus crispus), White-headed Duck (Oxyura leucocephala), Pallas's Sea Eagle (Haliaeetus leucoryphus), and Swan Goose (Anser cygnoides) (Batbayar and Tseveenmyadag 2009).

Field observations.-During our field observations, we conducted line-transect surveys during the day at each study site. In addition, we used diurnal and nocturnal visualencounter surveys (e.g., Heyer et al. 1994). Times varied for these surveys among study sites, but we conducted most diur- 
nal surveys between 0800 and $1200 \mathrm{~h}$ and most nocturnal surveys between 1900 and $2300 \mathrm{~h}$. We searched in and around bodies of water and marshes and under fallen branches and trees for amphibians and under and around bushes, in rocky areas, and under fallen logs for reptiles. We used published identification keys and field guides (Munkhbayar et al. 2001; Terbish et al. 2006) to identify species. For all species, excluding only the Moorfrog, we recorded only the number of animals detected. For the Moorfrog, we collected and preserved tissue samples (part of a toe) for subsequent molecular analysis in $70 \%$ ethanol and deposited them in the collection of the Biology Department of the Mongolian National University of Education in Ulaanbaatar. We recorded 15 measurements from $R$. arvalis $(\mathrm{n}=24)$ and five from Siberian Salamanders (Salamandrella keyserlingii; $\mathrm{n}=36$ ) to the nearest $0.1 \mathrm{~mm}$ using digital calipers.

Molecular experiments.-We used mitochondrial DNA (mtDNA) bar coding to ensure an accurate identification for Moorfrogs. We extracted genomic DNA from a piece of tissue from each specimen using DNeasy Blood and Tissue Kit (Qiagen, Hilden, Germany). We incubated tissues with tissue lysis buffer and proteinase $\mathrm{K}$ at $56{ }^{\circ} \mathrm{C}$ overnight and followed extraction procedures using the manufacturer's instructions. We amplified a 560-base-pair-long cytochrome c oxidase subunit-1 (COI) gene for $R$. arvalis using the following primer pair designed for this species: raF (5'-TCG AGC AGA ACT AAG CCA AC-3') and raR (5'- GGC AGG GTC AAA GAA GGT AG -3') using reference sequence HQ954807. We performed polymerase chain reactions (PCRs) with a final volume of $50 \mu \mathrm{l}$, which included $25 \mu \mathrm{l}$ HS prime premix, 2.0 $\mu \mathrm{l}$ of each primer, $16.0 \mu \mathrm{l}$ distilled water, and $5 \mu \mathrm{l}$ genomic DNA. The PCR condition for this reaction was an initial denaturation for $3 \mathrm{~min}$ at $94^{\circ} \mathrm{C}$, followed by 40 cycles at 94 ${ }^{\circ} \mathrm{C}$ for $1 \mathrm{~min}$, an extension at $72^{\circ} \mathrm{C}$ for $45 \mathrm{~s}$, and a final extension at $72{ }^{\circ} \mathrm{C}$ for $5 \mathrm{~min}$. We checked extracted gDNA and amplified PCR products under UV light with $1.5 \%$ agarose gels and compared our genetic sequences against previously published sequences of the species at the National Center for
Biotechnology Information (Johnson et al. 2008) using the BLAST tool. Results were accepted with $>99 \%$ certainty.

\section{Results}

We recorded six species of herpetofauna (Table 2; Fig. 2). Of these, three were amphibians ( 2 anurans and 1 salamander) from three families and three genera, whereas the remaining three were reptiles ( 2 lizards and 1 snake) from three families and three genera. We detected more species $(n=5)$ during the day than at night ( $\mathrm{n}=1$, only the Mongolian Toad, Strauchbufo raddei). Among study sites, Khyrgas Lake yielded more species ( $\mathrm{n}=3$, all reptiles), followed by Burenkhaan, Shar Uzuur, and Ulaan Taiga with two species each. The Tuvan Toad-headed Agama (Phrynocephalus versicolor) was the most frequently recorded species (Table 2). We documented only one species of the three amphibians at each study site (Table 2). Morphometric measurements for Rana arvalis $(\mathrm{n}=24)$ and Salamandrella keyserlingii $(\mathrm{n}=36)$ are in Table 3. All recorded species, except the Siberian Pitviper (Gloydius halys) (not assessed, NA) are listed as Least Concern (LC) in the IUCN Red List (IUCN 2018).

Significantly, we confirmed the presence of Moorfrogs in the Ulaan Taiga in Khuvsgul Province on 4 July 2019, 30 years after researchers first suggested the possible existence of this species in Mongolia. We did not find the species at any other sites. We identified $R$. arvalis using both morphological characteristics and mtDNA barcoding sequences conducted on six randomly selected individuals. We recorded $R$. arvalis at two localities within the Ulaan Taiga, namely along the Khar Busyn River (KBR) $\left(50^{\circ} 81^{\prime} \mathrm{N}, 98^{\circ} 02^{\prime} \mathrm{E}\right)$ and the Khuurai Khenien River (KHR) $\left(50^{\circ} 82^{\prime} \mathrm{N}, 98^{\circ} 03^{\prime} \mathrm{E}\right)$ (Fig. 3). These two localities are approximately $10 \mathrm{~km}$ apart on the western and eastern sides of Shar Kheryn Davaa Mountain (1,650 $\mathrm{m}$ asl), respectively. When we visited these two localities during the post-breeding season on 4 July, we did not observe any live or dead eggs or tadpoles in any ponds with and without frogs, and the majority of males lacked swollen fingers.

Table 2. Species of amphibians and reptiles recorded during surveys at sampling sites Burenkhaan (1), Khyrgas Lake (2), Naranbulag (3), Tavan Burgas (4), Shar Uzuur (5), and Ulaan Taiga (6) in northwestern Mongolia during herpetofaunal surveys in 2019.

\begin{tabular}{lccccccc} 
Species & $\mathbf{1}$ & $\mathbf{2}$ & $\mathbf{3}$ & $\mathbf{4}$ & $\mathbf{5}$ & $\mathbf{6}$ & Total \\
\hline Phrynocephalus versicolor Strauch 1876 & - & 14 & 12 & 6 & 8 & - & $\mathbf{4 0}$ \\
\hline Eremias multiocellata Gunther 1872 & - & 5 & - & - & 3 & - & $\mathbf{8}$ \\
\hline Gloydius halys Pallas 1776 & 1 & 1 & - & - & - & - & $\mathbf{2}$ \\
\hline Strauchbufo raddei Strauch 1876 & 28 & - & - & - & - & - & $\mathbf{2 8}$ \\
\hline Rana arvalis Nilsson 1842 & - & - & - & - & - & 24 & $\mathbf{2 4}$ \\
\hline Salamandrella keyserlingii Dybowski 1870 & - & - & - & - & - & 36 & 36 \\
\hline Number of species & 2 & 3 & 1 & 1 & 2 & 2 & 6 \\
\hline
\end{tabular}



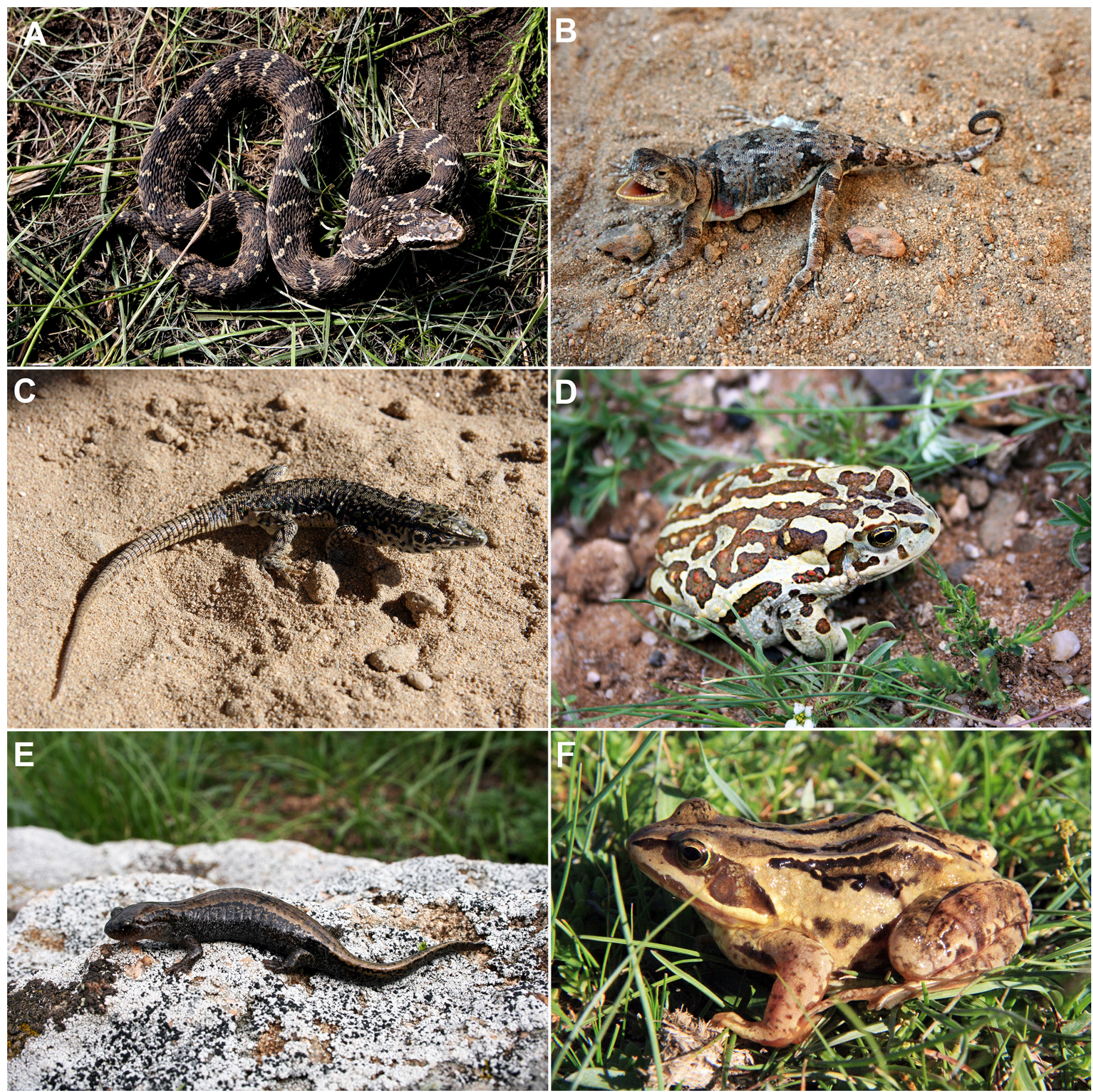

Fig. 2. Species recorded during surveys in northwestern Mongolia: (A) Siberian Pitviper (Gloydius halys); (B) Tuvan Toad-headed Agama (Phrynocephalus versicolor); (C) Multi-ocellated Racerunner (Eremias multiocellata); (D) Mongolian Toad (Strauchbufo raddei); (E) Siberian Salamander (Salamandrella keyserlingii); and (F) Moorfrog (Rana arvalis).

\section{Discussion}

We conducted the first herpetological surveys in northwestern Mongolia. Using a combination of methods, we recorded three species of amphibians ( $50 \%$ of previously recorded species) and three species of reptiles (14\% of previously recorded species) from our six study sites. During our surveys, we successfully recorded all amphibian species known to occur in this region but failed to document two species of previously recorded reptiles (the Gobi Racerunner, Eremias przewalskii, and the Steppe Ratsnake, Elaphe dione) with distributions that included our study sites. Landscapes in northern and western parts of Mongolia are mainly characterized by high mountains, taiga, and multiple types of forests, whereas grasslands dominate the eastern and central parts of the country, and semi-desert and desert landscapes occur mainly in southern Mongolia (Jambaajamts 1989). These geographical and cli- 
Table 3. Morphological measurements (mean \pm SD and range in $\mathrm{mm}$ ) for Moorfrogs (Rana arvalis) and Siberian Salamanders (Salamandrella keyserlingii). For $R$ arvalis $(\mathrm{n}=24)$ : SVL = snout-vent length, $\mathrm{HDL}=$ head length, $\mathrm{OOD}=$ interorbital distance, $\mathrm{SE}=$ snout-eye distance, $\mathrm{EL}=$ eye length, $\mathrm{SN}=$ snout-nostril distance, $\mathrm{IND}=$ internarial distance, $\mathrm{TD}=$ horizontal tympanum diameter, Do = dorsolateral fold distance, THIGH = thigh length, TL = tibia length, $\mathrm{TrL}=$ tarsus length, FOL = foot length (anuran measurements follow Fei et al. 2009). For S. keyserlingii $(\mathrm{n}=36)$ : SVL = snout-vent length, $\mathrm{TaL}=$ tail length, $\mathrm{HDL}=$ head length, FLL = forelimb length, HLL (hindlimb length.

\section{Moorfrog}

(Rana arvalis)

\begin{tabular}{lcll}
\hline SVL & $43.4 \pm 8.4(31.1-58.0)$ & SVL & $49.8 \pm 9.7(26.6-62.1)$ \\
\hline HDL & $15.5 \pm 3.7(10.2-23.3)$ & TaL & $36.3 \pm 4.3(29.0-41.0)$ \\
\hline IOD & $3.4 \pm 0.4(2.7-4.1)$ & HDL & $5.5 \pm 1.7(2.8-11.0)$ \\
\hline SE & $6.0 \pm 1.1(4.6-8.2)$ & FLL & $12.2 \pm 0.6(11.0-13.0)$ \\
\hline EL & $4.2 \pm 0.9(2.4-5.9)$ & HLL & $13.4 \pm 1.0(12.0-15.0)$ \\
\hline SN & $2.6 \pm 0.5(2.9-3.6)$ & & \\
\hline IND & $5.4 \pm 0.4(4.2-6.2)$ & & \\
\hline TD & $2.7 \pm 0.1(2.3-4.1)$ & & \\
\hline Do & $28.0 \pm 5.5(20.2-38.1)$ & & \\
\hline THIGH & $19.7 \pm 3.6(14.1-27.5)$ & & \\
\hline TL & $19.4 \pm 4.2(13.5-26.6)$ & & \\
\hline TrL & $10.3 \pm 1.7(7.8-14.1)$ & & \\
\hline FOL & $19.4 \pm 4.4(13.6-27.0)$ & & \\
\hline
\end{tabular}

\section{Siberian Salamanders}

\section{(Salamandrella keyserlingii)}

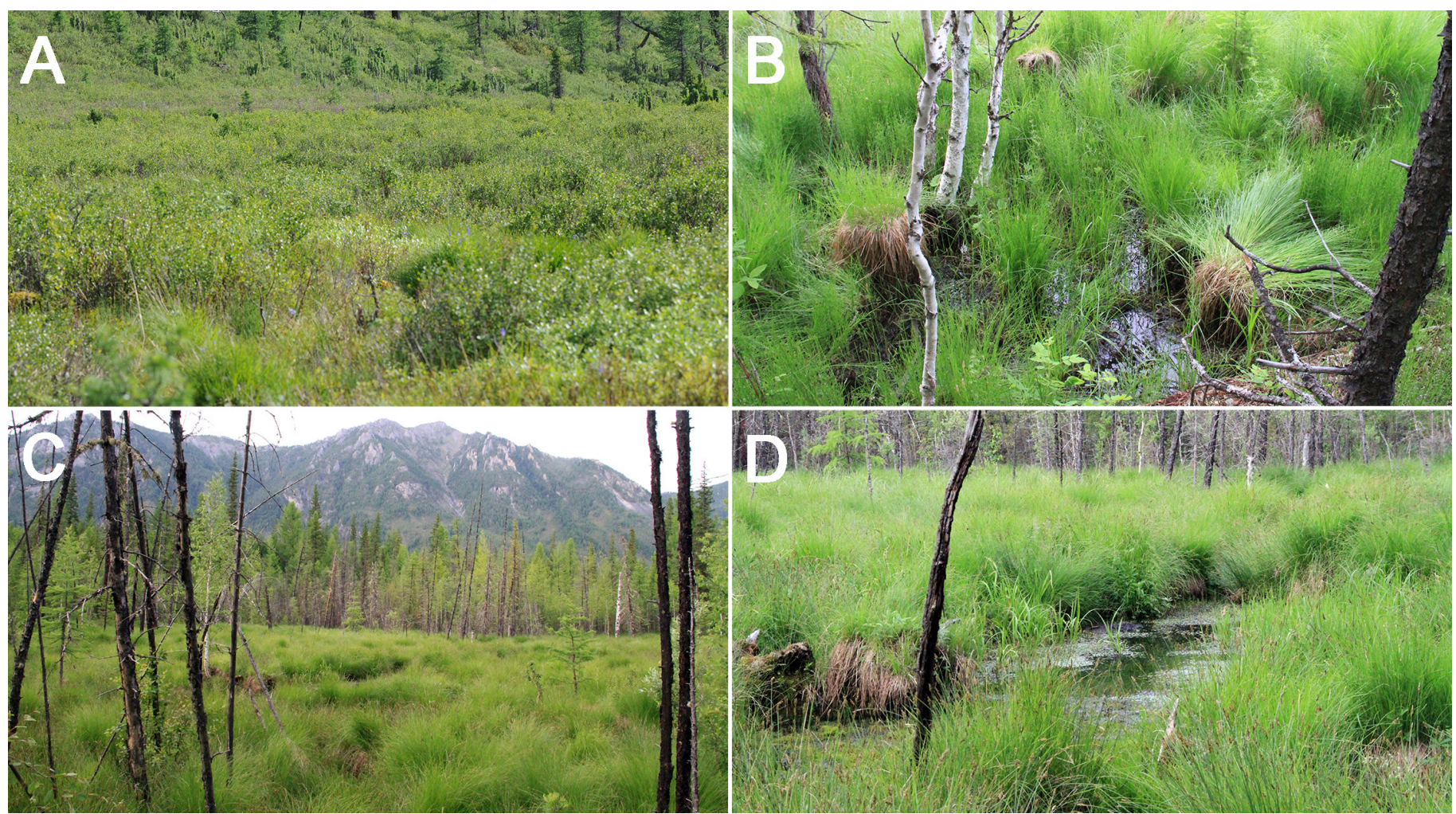

Fig. 3. Habitats of the Moorfrog (Rana arvalis) along the Khuurai Khenien River (A, B) and the Khar Busyn River (C, D) in Ulaan Taiga, Khuvsgul Province, Mongolia.

mactic conditions result in different distributions of herpetofauna and species richness, especially for amphibians. The majority of reptiles in Mongolia occur in the southern parts of the country, whereas most amphibians are limited to the north (Terbish et al. 2006; Kuzmin et al. 2017). Previous studies (Bannikov 1985; Borkin and Kuzmin 1988; Kuzmin et al. 
2017) found that Mongolian Toads (Strauchbufo raddei) had the widest distribution and used the most varied habitats of amphibians in Mongolia. In this study, we found 28 individuals only in Burenkhaan (part of the Delgermurun River Basin), suggesting that the species has a more limited distribution in the northern part of the country. Among reptiles recorded in Mongolia (and in this study), the Tuvan Toad-headed Agama (Phrynocephalus versicolor) is the most abundant and widely distributed reptile in the semi-desert and desert regions of Mongolia (Terbish et al. 2006b). Similarly, Yadamsuren et al. (2018) emphasized that this species might represent the most abundant vertebrate in some parts of Mongolia (see also Murdoch et al. 2010). Our surveys indicated that it is the most common herpetofaunal species in northwestern Mongolia (40 individuals recorded at four of six sites).

Thirty years after researchers first suggested the possible existence of Moorfrogs (Rana arvalis) in Mongolia, we documented the first records of the species from Ulaan Taiga in Khuvsgul Province on 4 July 2019. Because of its distribution in Russia, including Tuva and Buryatia, regions that border northern and northwestern Mongolia, some researchers (Borkin and Kuzmin 1988; Munkhbayar et al. 2001) had included the species among Mongolia's herpetofauna and Frost (2020) stated that the species is "expected in Mongolia but not yet recorded there.” Kuzmin et al. (2009) had suggested that the species might occur in the Altai Mountains and the Selenge and Orkhon River Basins; however, the Selenge and Orkhon River Basins were previously removed from the list of candidate regions because of habitat dissimilarities and because geographical barriers (mountains) isolated this region from the distribution of the species (Kuzmin 2012). Prior to our work, several expeditions had searched unsuccessfully for $R$. arvalis in Mongolia (Borkin and Kusmin 1988; Munkhbayar 2009; Terbish et al. 2006). As for the Altai Mountains, a research team (which included the first, second, and third authors of this study) conducted herpetofaunal field surveys in June and July of 2015 in the region and did not find $R$. arvalis.

Our failure to find eggs or tadpoles when we visited Ulaan Taiga after the breeding season is suggestive of reproductive failure or a lack of breeding activity. Kuzmin (1999) stated that $R$. arvalis in Russia lays eggs between March and June, eggs hatch after about three weeks, and metamorphosis occurs within the next 120 days. However, the time period for breeding and development of tadpoles depends strongly on environmental factors, such as air and soil temperatures. This indicates that additional biological and ecological surveys and research are needed to better understand the breeding characteristics and range of the species in Mongolia.

According to Terbish et al. (2006) and the IUCN (2018), a number of Mongolian species are listed as Data Deficient (DD) or Not Evaluated (NE) on both regional and global
Red Lists. That and results from this and previous studies are indicative of insufficient knowledge of Mongolian herpetofauna. Such inadequacies negatively affect our ability to develop effective conservation actions for these poorly studies species. Thus, to build a better conservation capacity in Mongolia, we need to increase the scope of investigations, including studies into habitat loss, reproductive success, factors affecting mortality, and the distributions of many species.

\section{Acknowledgements}

This study was funded by a research grant (SBR2019/07) from the Mongolian Foundation of Science and Technology. The first author also received a partial research grant from the Mongolian National University of Education. All procedures used in this study, including live capturing, photography, and tissue sampling adhered to the Guidelines for the Use of Live Amphibians and Reptiles in Field and Laboratory Research, $2^{\text {nd }}$ Edition, produced by the Herpetological Animal Care and Use Committee (HACC) (Beaupre et al. 2004). R. Reading provided useful comments and edits on the manuscript.

\section{Literature Cited}

Bannikov, A.G. 1958. Data on the fauna and biology of Amphibians and Reptiles in Mongolia. Bulletin of the Moscow Association of Nature Searchers, Section Biology 68(2): 71-91 (in Russian).

Batbayar, N. and N. Teveenmyadag (eds.). 2009. Directory of Important Bird Areas in Mongolia: Key Sites for Conservation. Wildlife Science and Conservation Center, Institute of Biology and Birdlife International, Ulaanbaatar, Mongolia.

Beaupre, S.J., E.R. Jacobson, H.B. Lillywhite, and K. Zamudio. 2004. Guidelines for Use of Live Amphibians and Reptiles in Field and Laboratory Research. American Society of Ichthyologists and Herpetologists, Lawrence, Kansas.

Borkin, L.Y. and S.L. Kuzmin. 1988. Amphibians of Mongolia: Species Account // Amphibians and Reptiles of the Mongolian People's Republic. General Problem. Amphibians. MKM Press, Moscow (in Russian).

Danzan, G. 1963. Zoological nomenclature. Proceedings of the Nomenclature of Mongolia 45-46: 1-121 (in Mongolian).

Fei, L., S.Q. Hu, C.Y. Ye, and Y.Z. Huang. 2009. Fauna Sinica, Amphibia: Volume 3. Anura Ranidae [M]. Science Press, Beijing, China (in Chinese).

Frost, D.R. 2020. Amphibian Species of the World: An Online Reference. Version 6.1. American Museum of Natural History, New York. <https://amphibiansoftheworld.amnh.org/index.php>.

Heyer, W.R., M.A. Donnelly, R.W. McDiarmid, L.C. Hayek, and M.S. Foster. 1994. Measuring and Monitoring Biological Diversity: Standard Methods for Amphibians. Smithsonian Institution Press, Washington, DC.

IUCN (International Union for Conservation of Nature). 2018. The IUCN Red List of Threatened Species. Version 2016.3. <http://www.iucnredlist.org>.

Jambaajamts, A. 1989. Climate Brief Overview of Republic of Mongolia. National Press Office, Ulaanbaatar, Mongolia.

Johnson, M., I. Zaretskaya, Y. Raytselis, Y. Merezhuk, S. McGinnis, and T.L. Madden. 2008. NCBI BLAST: a better web interface. Nucleic Acids Research 36 (Web Server issue): W5-W9.

Kozlov, P.K. 1949. Travels to Mongolia in 1923-1926. Geography Institute, Moscow, Russia (in Russian).

Kuzmin, S.L. 1999. The Amphibians of the Former Soviet Union. Pensoft Press, Moscow, Russia (in Russian).

Kuzmin, S.L. 2012. The Amphibians of the Former USSR. 2nd edition. KMK Scientific Press Ltd., Moscow, Russia (in Russian).

Kuzmin, S.L., D. Tarkhnishvili, V. Ishchenko, B. Tuniyev, T. Beebee, B.P. Anthony, B. Schmidt, A. Ogrodowczyk, M. Ogielska, W. Babik, M. Vogrin, J. Loman, D. Cogalniceanu, T. Kovács, and I. Kiss. 2009. Rana arvalis (errata 
version published in 2016). The IUCN Red List of Threatened Species 2009: e.T58548A86232114.

Kuzmin, S.L., E.A. Dunayev, Kh. Munkhbayar, M. Munkhbaatar, J. Oyunchimeg, and Kh. Terbish. 2017. The Amphibians of Mongolia. KMK Scientific Press Ltd., Moscow, Russia (in Russian).

Munkhbaatar, M. 2003. The Amphibians and Reptiles of Eastern Mongolia. Unpublished Ph.D. Thesis, Mongolian State University of Education, Ulaanbaatar, Mongolia (in Mongolian).

Munkhbayar, Kh. 1971. The new subspecies of Mongolian agama - Agama stolizkana altaica subsp. nov. Proceedings of the Mongolian Academy of Science 4: 116-117 (in Mongolian).

Munkhbayar, Kh. 2009. Herpetological studies in 2009. Research Works of School of Natural Science, Mongolian State University of Education 2: 57-72 (in Mongolian).

Munkhbayar, Kh., Kh. Terbish, and M. Munkhbaatar. 2001. Key to Amphibians and Reptiles Mongolia. Munkhyn Useg Press, Ulaanbaatar, Mongolia (in Mongolian).

Murdoch, J.D., B. Suuri, and R.P. Reading. 2010. Estimates of Toad Headed
Agama density in three steppe habitats of Mongolia. Erforschung Biologischer Ressourcen der Mongolei 11: 383-389.

Olziikhutag, N. 1989. Outline of Mongolian Flora. State Press Publishing House, Ulaanbaatar, Mongolia.

Pope, C.H. 1931. Notes on amphibians from Fukien, Hainan and other parts of China. Bulletin of the American Museum of Natural History 61: 397-612.

Potanin, G.N. 1889. The Tangut-Tibetan Frontier of China and Central Mongolia. Geography Institute, Moscow, Russia (in Russian).

Shagdarsuren, O. 1958. A study of Mongolian amphibians and reptiles. Science and Technique 3: 18-20 (in Mongolian).

Terbish, Kh., Kh. Munkhbayar, E.L. Clark, J. Munkhbat, E.M. Monks, M. Munkhbaatar, and D.V. Semenov. 2006. Mongolian Red List of Reptiles and Amphibians. Regional Red List Series. Vol. 5. Zoological Society of London, London, United Kingdom.

Yadamsuren, O., J.D. Murdoch, S. Chuluunbat, E. Purevee, M. Munkhbayar, A. Jargalsaikhan, and T. Khayankhyarvaa. 2018. Estimating occupancy and detectability of Toad Headed Agamas at the periphery of their range in Mongolia. Journal of Herpetology 52: 361-368. 